\begin{tabular}{c|c|c}
\hline \hline Vol. 261: 149-159, 2003 & MARINE ECOLOGY PROGRESS SERIES \\
Mar Ecol Prog Ser & Published October 17 \\
\hline
\end{tabular}

\title{
Phytotoxicity of Photosystem II (PSII) herbicides to coral
}

\author{
Ross J. Jones*, Ailsa P. Kerswell \\ Centre for Marine Studies, The University of Queensland, St Lucia Campus, Brisbane, Queensland 4072, Australia
}

\begin{abstract}
Recent reports of contamination of the Great Barrier Reef Marine Park by herbicides used in antifouling paints and in agriculture have caused concern over the possible effects on corals in nearshore areas. Pulse-Amplitude Modulated (PAM) chlorophyll fluorescence techniques were used to examine changes in the maximum effective quantum yield $\left(\Delta F / F_{\mathrm{m}}{ }^{\prime}\right)$ of symbiotic dinoflagellates within the host tissues (in hospite) of the coral Seriatopora hystrix exposed to a number of Photosystem II (PSII) inhibiting herbicides in short-term toxicity tests. The concentration of herbicide required to reduce $\Delta F / F_{\mathrm{m}}{ }^{\prime}$ by $50 \%$ (median effective concentration [ $\left.\mathrm{EC}_{50}\right]$ ) differed by over 2 orders of magnitude: Irgarol $1051\left(0.7 \mu \mathrm{g} \mathrm{l}^{-1}\right)>$ ametryn $\left(1.7 \mu \mathrm{g} \mathrm{l}^{-1}\right)>\operatorname{diuron}\left(2.3 \mu \mathrm{g} \mathrm{l}^{-1}\right)>$ hexazinone $(8.8 \mu \mathrm{g}$ $\left.\mathrm{l}^{-1}\right)>$ atrazine $\left(45 \mathrm{~g} \mathrm{l}^{-1}\right)>$ simazine $\left(150 \mu \mathrm{g} \mathrm{l}^{-1}\right)>$ tebuthiuron $\left(175 \mathrm{~g} \mathrm{l}^{-1}\right)>$ ionynil $\left(>1 \mathrm{mg} \mathrm{l}^{-1}\right)$. Similar absolute and relative toxicities were observed with colonies of the coral Acropora formosa (Irgarol $1051 \mathrm{EC}_{50}: 1.3 \mu \mathrm{g} \mathrm{l}^{-1}$, diuron $\mathrm{EC}_{50}: 2.8 \mu \mathrm{g} \mathrm{l^{-1 }}$ ). Time-course experiments indicated that $\Delta F / F_{\mathrm{m}}{ }^{\prime}$ was rapidly reduced (i.e. within minutes) in S. hystrix exposed to Irgarol 1051 and diuron. On return to fresh running seawater, $\Delta F / F_{\mathrm{m}}$ ' recovered quickly in diuron-exposed corals (i.e. in minutes to hours), but slowly in corals exposed to Irgarol 1051 (i.e. hours to days). Time-course experiments indicated that the effects of diuron $\left(3 \mu \mathrm{g} \mathrm{l}^{-1}\right)$ on $S$. hystrix were inversely related to temperature over the range 20 to $30^{\circ} \mathrm{C}$, although initially the effects were less at the lower temperatures. Repeated exposure to pulses of Irgarol 1051 (daily $2 \mathrm{~h}$ exposure to $30 \mu \mathrm{g} \mathrm{l^{-1 }}$ over $4 \mathrm{~d}$ ) resulted in a $30 \%$ decrease in the density of symbiotic dinoflagellates in the tissues of S. hystrix.
\end{abstract}

KEY WORDS: Coral · Coral bleaching · Symbiotic dinoflagellate $\cdot$ Irgarol $1051 \cdot$ Diuron $\cdot$ Herbicide Chlorophyll fluorescence

Resale or republication not permitted without written consent of the publisher

\section{INTRODUCTION}

Contamination of the Queensland (Australia) tropical marine environment by herbicides has recently been reported in several studies. Scarlett et al. (1999a) reported the presence of the herbicide Irgarol 1051 (Ncyclopropyl-N'-(1,1-dimethylethyl)-6-(methylthio)-1,3,5triazine-2,4-diamine) in seagrass samples at several locations along the east coast of Australia, including areas within the Great Barrier Reef Marine Park (GBRMP). Haynes et al. (2000) reported the presence of diuron ( $N^{\prime}$-(3,4-dichlorophenyl)- $N, N$-dimethylurea) in intertidal sediments and seagrasses in the northern section of the GBRMP, and in intertidal seagrass samples collected near Townsville $\left(18^{\circ} \mathrm{S}\right)$. Duke et al. (2001) reported diuron and ametryn contamination in coastal sediments near Mackay $\left(21^{\circ} \mathrm{S}\right)$. The source of the contamination, particularly with respect to diuron, has been the subject of considerable scientific and political attention because some of the sites fall within the Great Barrier Reef World Heritage Area.

Approximately $50 \%$ of commercially available herbicides, including Irgarol 1051, diuron and ametryn, act by inhibiting the chloroplast electron transport chain. Their mode of action is associated with competition with plastoquinone for the $\mathrm{Q}_{\mathrm{B}}$ binding site (niche) of photosynthesis on the D1 or 'herbicide-binding' protein (for a review on Photosystem [PS] II herbicides see Oettmeier 1992, see also Jones et al. 2003). When temporarily bound, herbicides disrupt photosynthetic electron flow, and in illuminated samples excitation energy is lost as fluorescence as opposed to being trapped by 
a photosynthetic reaction centre. In addition to groupings according to their site of action, herbicides can be further subdivided into separate chemical families. Chemical families of PSII inhibitors include, amongst others, the phenyl ureas (including diuron and tebuthiuron), s-triazines (including Irgarol 1051, simazine, ametryn), triazinones (including hexazinone), uracils, nitriles (including ioxynil), benzothiadiazoles and phenyl-pyridazines.

Both diuron and Irgarol 1051 are found in antifouling paint formulations, where they function to prevent the growth of algae. Their use in antifouling paints stemmed from restrictions on the use of tri-n-butyltin (TBT) in the 1980s and the realization that in some instances antifouling could not be achieved by relying solely on copper as a biocide (Dahl \& Blanck 1996, Voulvoulis et al. 1999). To function as antifoulants, biocides leach or dissolve from the paint matrix, creating a chemically active boundary layer that prevents, or reduces, attachment and growth of colonizing organisms (Evans 1981). Release of herbicides to the marine environment is thus intentional and a necessary consequence of their mode-of-action. In Australia, there are currently 21 registered antifouling paint formulations containing diuron, usually as a co-biocide with copper oxide and copper thiocyanate (Table 1). Although registered in many countries worldwide, Irgarol 1051 has not yet been registered in Australia, and contamination of the GBR reported by Scarlett et al. (1999a) is most probably through the sale of unregistered antifouling paint.

Diuron is a broad-spectrum herbicide, registered for use in Australia for pre- and post-emergence control of both broadleaf and grass weeds in many different

Table 1. Currently registered products in Australia containing diuron as the only active constituent, or in combination with cuprous oxide $\left(\mathrm{Cu}_{2} \mathrm{O}\right)$, cuprous thiocyanate $(\mathrm{CuSCN})$ or other herbicides and fungicides. Data from the Australian Pesticides and Veterinary Chemicals (APVMA, formerly the National Registration Authority for Agricultural and Veterinary chemicals [NRA]) registered product database (PUBCRIS). 'Others' include: (1) 2,2dichloro-proprionic acid (halogenated aliphatic herbicide) and amitrol (triazole, bleaching herbicide); (2) hexazinone (triazinone, PSII herbicide) and bromacil (uracil, PSII herbicide); (3) thidiazuron (thiadiazolylurea, PSII herbicide); (4) CuSCN and zinc oxide; (5) chlorothalonil (fungicide) and $\mathrm{Cu}_{2} \mathrm{O}$

\begin{tabular}{|c|c|c|}
\hline Agricultural herbicides & Antifouling paints & Algaecides $^{\mathrm{a}}$ \\
\hline Diuron only: 44 & Diuron only: 0 & \multirow[t]{4}{*}{ Diuron only: 3} \\
\hline Diuron \& hexazinone: 7 & Diuron \& $\mathrm{Cu}_{2} \mathrm{O}: 18$ & \\
\hline Diuron \& bromacil: 3 & \multirow[t]{2}{*}{ Diuron \& CuSCN: 3} & \\
\hline Diuron \& 'Others': 6 & & \\
\hline Total: 60 & Total: 21 & Total: 3 \\
\hline
\end{tabular}

crops. In Queensland, it is used mostly in the sugarcane, cotton and pineapple industries. Currently, diuron is registered as an active ingredient in 60 herbicide formulations, either as a sole biocide (44 registered products) or in combination with other herbicides or a fungicide (16 registered products, Table 1). In Queensland an estimated $197 \mathrm{t}$ of diuron are used annually in sugar cane cultivation alone (Hamilton \& Haydon 1996). Peak application is usually in the austral spring/summer (between November and January) each year. The potential for 'offsite' movement of herbicides has regularly been reported (for example Müller et al. 2000, Hunter et al. 2001), and the significance of the 'first flush' (the first substantial rainfall event of the year that may wash out a high proportion of the herbicides that have accumulated in the catchment throughout the dry season) is regularly emphasized (Mitchell et al. 1996). The potential for downstream contamination by herbicides has been shown in a detailed study of the Pioneer River catchment (Mackay Region, Central Queensland) following a moderate (1 in 2 yr) 'highflow' rainfall event of the 2001 to 2002 wet season. Riverine water quality measurements over a $3 \mathrm{~d}$ period in February 2002 indicated peak diuron concentrations of $8.5 \mu \mathrm{g} \mathrm{l}^{-1}$ diuron and an estimated total loss of $470 \mathrm{~kg}$ of diuron from the catchment area, corresponding to a loss of 2 to $4 \%$ of the annual application (Simpson 2002, White et al. 2002).

Many recent reviews of GBR water quality have identified a critical need for information with respect to the biological effects of pesticides, especially herbicides, on flora and fauna of the GBRMP (Scarlett et al. 1999a, Haynes \& Michalek-Wagner 2000, Haynes et al. 2000, Hutchings \& Haynes 2000, Williams 2001). Most of the reviews highlight the importance of examining the inshore areas of the GBR, i.e. coastal areas containing mangroves, soft-bottom communities, seagrasses and fringing reef environments. These areas receive the bulk of the terrigenous inputs from the 25 major river catchments discharging directly into the GBRMP (Larcombe et al. 1996). Several of the reviews have particularly highlighted the need to examine the effects of herbicides on corals and their symbiotic dinoflagellates. A number of reviews specifically highlight the need to examine the herbicide diuron, and the potential synergistic effects of variables such as temperature and reduced salinity. This information is crucial for the impending review of diuron usage in Australia scheduled by the Australian Pesticides and Veterinary Medicines Authority (APVMA).

A few studies have examined the effects of herbicides on corals, but have either used non-PSII-based herbicides, or have been associated with understanding the nature of coral-algal symbiosis and have used exceptionally high concentrations. Glynn et al. (1984) 
reported no effects following $24 \mathrm{~h}$ exposure of the coral Pocillopora damicornis to $0.05,0.1$ and $1 \mathrm{mg} \mathrm{l}^{-1}$ of 2,4dichlorophenoxyacetic acid $(2,4-\mathrm{D})$, a plant growth hormone herbicide. Shick et al. (1999) used glyphosate (N-(phosphonomethyl)-glycine), a specific inhibitor of the shikimate pathway, to examine how UV sunscreening compounds (mycosporine-like amino acids) are synthesized in corals. Banin et al. (2001) used phenyl ureas to examine the role of symbiotic dinoflagellate photosynthesis in the synthesis or secretion of a receptor responsible for adhesion of the bacteria Vibrio shiloi to the coral Oculina patagonica. Diuron has also been used to examine the nature of the bacterial consortia associated with black band disease corals (Richardson et al. 2001). Several other studies have used diuron to understand how skeletal deposition of corals is enhanced by photosynthesis of the symbiotic dinoflagellates (light-enhanced calcification) but have used concentrations in the range of 0.1 to $1 \mathrm{mg} \mathrm{l}^{-1}$ (Vandermeulen et al. 1972, Crossland \& Barnes 1977, Barnes 1985, Marshall \& Wright 1998).

Complementing an earlier study on the effects of diuron and atrazine on corals of the GBR (Jones et al. 2003), this paper addresses the herbicidal properties of a number of different PSII-based herbicides. Specific attention is paid to the effects of 2 herbicides, Irgarol 1051 and diuron, and the kinetics associated with their phytotoxicity and the recovery time on their return to clean flowing seawater. Temperature is examined as a co-variable with respect to diuron toxicity.

\section{MATERIALS AND METHODS}

All experiments were conducted at the Heron Island Research Station in the Capricorn-Bunker group of reefs in the southern GBR, Australia. Experiments were conducted with branches of Acropora formosa (Dana 1846; family Acroporidae) living on the inner subtidal protected reef flat of Heron Island reef and branches of Seriatopora hystrix (Dana 1846; family Pocilloporidae) from colonies located on the top of the protected subtidal reef slope. Both A. formosa and S. hystrix are commonly found at Heron Island and are widely distributed throughout the Indo-Pacific (Veron 1986). For A. formosa, vertically oriented branches (4 to $6 \mathrm{~cm}$ long) were cut from the centre of colonies using surgical bone cutters, and the bases of the cut branches were sealed with a 2 part epoxy polymer (Selleys Pty), then modelling clay was used to mount them into plastic holders. For experiments with $S$. hystrix, small (1 to $2 \mathrm{~cm}$ long) vertically oriented single or bifurcated branches were cut from the top of the central areas of the colonies and attached to the numbered plastic holders. Before any experiments were carried out, all coral fragments were maintained for at least 1 to $2 \mathrm{~d}$ in a holding tank that received a supply of running seawater. Light levels in the holding tank were reduced to $50 \%$ (A. formosa) or $25 \%$ (S. hystrix) by placing neutral density shade-cloth above the test corals.

Toxicity tests with coral colonies. Short-term (24 h), static toxicity tests were conducted to examine the phytotoxicity of the herbicides ametryn ( $N$-ethyl- $N^{\prime}$ (1-methylethyl)-6-(methylthio)-1,3,5-triazine-2,4-diamine), atrazine (6-chloro- $N$-ethyl- $N^{\prime}$-(1-methylethyl)1,3,5-triazine-2,4-diamine), diuron ( $N^{\prime}$-(3,4-dichlorophenyl)- $N, N$-dimethylurea), hexazinone (3-cyclohexyl-6-(dimethylamino)-1-methyl-1,3,5-triazine-2,4(1H, 3H)-dione), ioxynil (4-hydroxy-3,5-diiodobenzonitrile), Irgarol 1051 (N-cyclopropyl-N'-(1,1-dimethylethyl)-6-(methylthio)-1,3,5-triazine-2,4-diamine), simazine (6-chloro- $N, N^{\prime}$-diethyl-1,3,5-triazine-2,4-diamine) and tebuthiuron (N-[5-(1,1-dimethylethyl)1,3,4-thiadiazol-2-yl]- $N, N^{\prime}$-dimethylurea) on the symbiotic dinoflagellates of Seriatopora hystrix, and of diuron and Irgarol 1051 on Acropora formosa. Experimental conditions during the short-term toxicity tests have been described previously (Jones et al. 2003); briefly, tests were conducted for $24 \mathrm{~h}$ in $200 \mathrm{ml}(S$. hystrix) or 21 (A. formosa) of test solution at $25 \pm 1^{\circ} \mathrm{C}$ under artificial lights $\left(120 \mu \mathrm{mol}\right.$ quanta $\mathrm{m}^{-2} \mathrm{~s}^{-1}$ photosynthetically active radiation [PAR] 400 to $700 \mathrm{~nm}$ for $A$. formosa or $25 \mu$ mol quanta $\mathrm{m}^{2} \mathrm{~s}^{-1}$ PAR for $S$. hystrix) under a $10 \mathrm{~h}$ light:14 h dark cycle. Test solutions were made using $1 \mu \mathrm{m}$ filtered seawater with stock solutions and acetone as a carrier. For each toxicity test, 5 test concentrations and 1 control (filtered seawater + carrier only) were used and 3 randomly located replicate containers (with 3 or 4 corals per container) were used at each concentration or control. Chlorophyll fluorescence parameters (see subsection below) were determined at $t=10 \mathrm{~h}$ (the maximum effective quantum yield, $\Delta F / F_{\mathrm{m}}{ }^{\prime}$ ) and $t=24 \mathrm{~h}$ (the maximum potential quantum yield, $F_{V} / F_{\mathrm{m}}$ ) and corals were returned to the holding tank and $\Delta F / F_{\mathrm{m}}{ }^{\prime}$ determined in the late afternoon (16:00 h) over successive days.

To examine the time-course of the herbicides' action, fragments of Seriatopora hystrix were exposed to $3 \mu \mathrm{g}$ $\mathrm{l}^{-1}$ diuron or Irgarol 1051, or the acetone carrier only and $\Delta F / F_{\mathrm{m}}{ }^{\prime}$ determined at $10 \mathrm{~min}$ intervals for the first hour and then at approximately 20 and 40 min intervals for the second and third hours respectively. The corals were then transferred to a 301 aquarium that received a supply of running seawater $\left(31 \mathrm{~min}^{-1}\right)$ and $\Delta F / F_{\mathrm{m}}{ }^{\prime}$ determined at regular intervals for a further $5.5 \mathrm{~h}$. Both experiments were conducted under $30 \mu \mathrm{mol}$ quanta $\mathrm{m}^{-2} \mathrm{~s}^{-1}$ PAR. Corals were then transferred to the outdoor holding tank and $\Delta F / F_{\mathrm{m}}$ ' determined in the late afternoon $(16: 00 \mathrm{~h})$ for 3 successive days. Three replicate containers (each containing 4 corals) were used for each control or herbicide concentration. 
To examine the lowest observed effect concentration (LOEC, lowest tested concentration causing an effect) values of Irgarol 1051 or diuron in hospite, $\Delta F / F_{\mathrm{m}}{ }^{\prime}$ was measured in fragments of Seriatopora hystrix every $5 \mathrm{~min}$ for $1 \mathrm{~h}$ before and $1.5 \mathrm{~h}$ after transfer to a herbicide solution (diuron or Irgarol 1051, range 50 to $300 \mathrm{ng} \mathrm{l}^{-1}$ ) or control (acetone carrier only). All experiments were conducted at $25 \pm 1^{\circ} \mathrm{C}$ under artificial lighting (30 $\mathrm{\mu mol}$ quanta $\left.\mathrm{m}^{-2} \mathrm{~s}^{-1} \mathrm{PAR}\right)$.

To examine the effects of temperature on herbicide toxicity, fragments of Seriatopora hystrix were exposed to $3 \mathrm{\mu g} \mathrm{l}^{-1}$ diuron or control solutions (acetone carrier only) at temperatures of $22,24,26,28$ and $30^{\circ} \mathrm{C}$. At each temperature, 3 replicate $200 \mathrm{ml}$ glass beakers were used for both control and diuron-exposed treatments, with 4 coral fragments per beaker. At the start of the experiment, beakers were semi-immersed in a 301 water-baths maintained at the designated temperature with $200 \mathrm{~W}$ submersible electronic aquarium heaters. Two magnetic stirrers were used to stir each water bath and periodic testing indicated temperatures within the water bath and enclosed beakers were within $\pm 0.5^{\circ} \mathrm{C}$ of the desired temperature levels. The experiment was conducted under $30 \mu \mathrm{mol}$ quanta $\mathrm{m}^{-2}$ $\mathrm{s}^{-1} \mathrm{PAR}$, and all fluorescence measurements were made under the same irradiance intensity. At the beginning of the experiments, corals were transferred from a holding tank at $25^{\circ} \mathrm{C}$ and placed directly in the test or control solutions at the desired temperatures. $\Delta F / F_{\mathrm{m}}{ }^{\prime}$ was measured at $1,2,4,6$ and $8 \mathrm{~h}$. During measurements, $\Delta F / F_{\mathrm{m}}$ ' was determined in corals in 1 of the 3 replicate containers, sequentially from the coolest to the warmest temperatures and in the control treatments, before the herbicide treatments. The fluorometer fibre-optic was then washed thoroughly (to prevent cross contamination), and $\Delta F / F_{\mathrm{m}}{ }^{\prime}$ determined in the same sequence in the second of the 3 replicates at each temperature and each treatment. The process was then repeated for the third replicate.

The effects of repeated exposure to $30 \mu \mathrm{g} \mathrm{l}^{-1}$ Irgarol 1051 were examined using small colonies (4 to $5 \mathrm{~cm}$ diameter) of Seriatopora hystrix. During these studies, colonies $(\mathrm{n}=3)$ were incubated for $2 \mathrm{~h}$ (between 08:00 and 10:00 h) in 21 solutions of either $30 \mu \mathrm{g} \mathrm{l^{-1 }}$ Irgarol 1051 or seawater only (+ carrier). Four separate containers (each containing 3 corals) were used for each treatment (Irgarol 1051 or control). During the incubations, water was stirred using gentle bubbling provided by aquarium pumps, and after a $2 \mathrm{~h}$ exposure period, corals were transferred to a 5001 holding tank that received a running supply of fresh seawater. Exposure to Irgarol 1051 or the carrier only (control solutions) was repeated over the same period each day for 4 consecutive days. During the $2 \mathrm{~h}$ incubation periods and the $22 \mathrm{~h}$ recovery period in flowing seawater, corals were incubated under ambient light, manipulated using layers of neutral density shade-cloth so that maximum PAR did not exceed $50 \mu \mathrm{mol}$ quanta $\mathrm{m}^{-2} \mathrm{~s}^{-1}$ PAR. Light levels were recorded at $10 \mathrm{~min}$ intervals using a terrestrial cosine photosynthetic irradiance sensor (see Jones et al. 2003). Water temperature ranged between 23 and $26^{\circ} \mathrm{C}$ over the duration of the test. $\Delta F / F_{\mathrm{m}}{ }^{\prime}$ was measured each day in the late afternoon (between 16:00 and 17:00 h) in all treatments. Immediately preceding and during the first $24 \mathrm{~h}$ of the test, $\Delta F / F_{\mathrm{m}}{ }^{\prime}$ was measured at $10 \mathrm{~min}$ intervals in 1 colony of $S$. hystrix exposed to $30 \mu \mathrm{g} \mathrm{l}^{-1}$ Irgarol for $2 \mathrm{~h}$ (between 08:00 and 10:00 h) and then transferred to running seawater. At the end of the $4 \mathrm{~d}$ experiment, small $(1$ to $2 \mathrm{~cm}$ ) vertically oriented branches were excised from the parent colonies and frozen for later determination of symbiotic dinoflagellate density.

Coral tissues were stripped from the skeletons with a jet of re-circulated filtered seawater $(\sim 100 \mathrm{ml})$ using a WaterPik ${ }^{\mathrm{TM}}$ and the number of symbiotic dinoflagellates in $10 \mathrm{ml}$ aliquots of the homogenate was determined with a haemocytometer using the techniques outlined in Jones et al. (2003). The density of symbiotic algae was expressed as number per $\mathrm{cm}^{2}$, and the surface area was determined using the paraffin wax adhesion technique (Stimson \& Kinzie 1991).

All experiments conducted here were static (nonrenewal and renewal) and all herbicide-contaminated seawater was shipped from Heron Island for disposal on the mainland.

Chlorophyll fluorescence measurements. Chlorophyll fluorescence parameters of symbiotic dinoflagellates still in the host tissue of the coral (in hospite or in vivo) were measured using a DIVING-PAM chlorophyll fluorometer (Walz) on vertical planes of tissue 2 to $3 \mathrm{~cm}$ above the base of the corals, using either a $6 \mathrm{~mm}$ (Acropora formosa) or $2 \mathrm{~mm}$ (Seriatopora hystrix) fibre-optic probe. Parameters measured include the maximum potential quantum yield $\left(F_{V} / F_{\mathrm{m}}\right)$ and maximum effective quantum yield $\left(\Delta F / F_{\mathrm{m}}{ }^{\prime}\right)$; see Jones et al. (2003) for procedures and instrument settings.

Data analysis. Hypothesis testing and point estimate procedures were used to assess the toxicity of the herbicides using 3 statistical parameters. No observed effect concentration (NOEC, the highest concentration not producing a significant response) and the LOEC were calculated using arcsine-transformed data. Data passing the test for normality of distribution (Kolmogorov $D$-test) and homogeneity of variance (Bartlett's test) were analyzed using analysis of variance (ANOVA) and Dunnett's test to examine significant differences between herbicide-treated and control (solvent only; see Rand \& Petrocelli 1985) corals. Data that did not pass the criteria were analyzed using Steel's Many-One Rank test. The concentrations caus- 


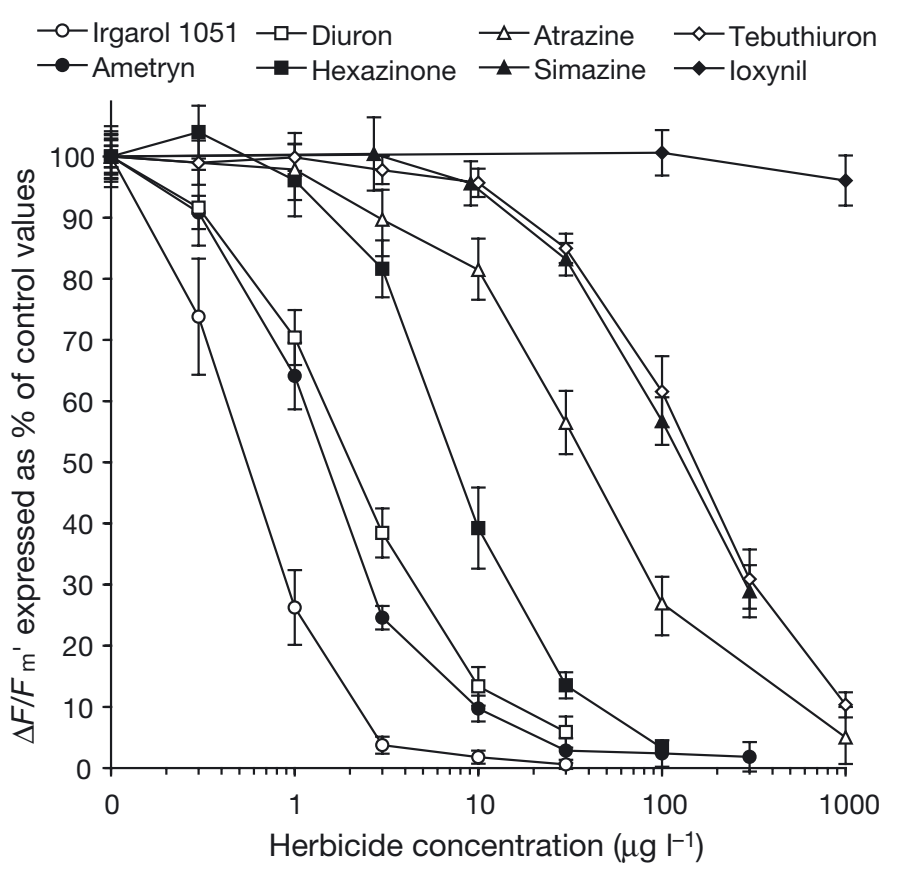

Fig. 1. Seriatopora hystrix. $\Delta F / F_{\mathrm{m}}{ }^{\prime}$ of symbiotic dinoflagellates (in hospite) in S. hystrix exposed to elevated Irgarol 1051, ametryn, diuron, hexazinone, atrazine, simazine, tebuthiuron or ioxynil (range 0.3 to $1000 \mu \mathrm{g} \mathrm{l}^{-1}$ ) for $10 \mathrm{~h}$. All experiments were conducted at $25 \pm 1^{\circ} \mathrm{C}$ under $30 \mu \mathrm{mol}$ quanta $\mathrm{m}^{-2} \mathrm{~s}^{-1}$ artificial light. Data are normalized to control coral (exposed to carrier only) and expressed as mean $(\bar{x}) \pm \operatorname{SD}(n=12)$

ing a 50 and $25 \%$ reduction in the effect parameter $\left(\mathrm{EC}_{50}\right.$ and $\left.\mathrm{EC}_{25}\right)$ were calculated using the liner interpolation method (Icp). All calculations were made using (ToxCalc ${ }^{\mathrm{TM}}$ version 5.0, Tidepool Scientific software) and expressed as mean $(\bar{x}) \pm$ SD.

\section{RESULTS}

In the short-term $(10 \mathrm{~h})$ toxicity tests, changes in $\Delta F / F_{\mathrm{m}}{ }^{\prime}$ were used to assess the relative toxicity of a number of herbicides to Seriatopora hystrix and Acropora formosa. In S. hystrix, Irgarol 1051 was most phytotoxic $\left(\mathrm{EC}_{50}: 0.7 \pm 0.03, \mathrm{EC}_{25}: 0.3 \pm 0.03\right.$, NOEC: $<0.3$, LOEC: $\left.0.3 \mu \mathrm{g} \mathrm{l}^{-1}\right)$ followed by ametryn $\left(\mathrm{EC}_{50}: 1.7\right.$ $\pm 0.1, \mathrm{EC}_{25}: 0.71 \pm 0.03$, NOEC: $<0.3$, LOEC: $\left.0.3 \mu \mathrm{g} \mathrm{l}^{-1}\right)$, diuron $\left(\mathrm{EC}_{50}: 2.3 \pm 0.04, \mathrm{EC}_{25}: 0.85 \pm 0.03\right.$, NOEC: $<0.3$, LOEC: $\left.0.3 \mu \mathrm{g} \mathrm{l}^{-1}\right)$, hexazinone $\left(\mathrm{EC}_{50}: 8.8 \pm 1, \mathrm{EC}_{25}: 4.3\right.$ \pm 1 , NOEC: 1 , LOEC: $\left.3 \mu \mathrm{g} \mathrm{l}^{-1}\right)$, atrazine $\left(\mathrm{EC}_{50}: 45 \pm 3\right.$, $\mathrm{EC}_{25}: 15 \pm 1.2$, NOEC: 1 , LOEC: $3 \mu \mathrm{g} \mathrm{l^{-1 }}$ ), simazine $\left(\mathrm{EC}_{50}: 150 \pm 7, \mathrm{EC}_{25}: 55 \pm 5\right.$, NOEC: 10, LOEC: $30 \mu \mathrm{g}$ $\left.\mathrm{l}^{-1}\right)$, tebuthiuron $\left(\mathrm{EC}_{50}: 175 \pm 7, \mathrm{EC}_{25}: 60 \pm 2.5\right.$, NOEC: 3, LOEC: $\left.10 \mu \mathrm{g} \mathrm{l}^{-1}\right)$ and ioxynil $\left(\mathrm{EC}_{50}\right.$ and $\mathrm{EC}_{25}$ : $>1000 \mu \mathrm{g} \mathrm{l}^{-1}$, NOEC: $>1000 \mu \mathrm{g} \mathrm{l}^{-1}$, Fig. 1). In A. formosa, Irgarol $1051\left(\mathrm{EC}_{50}: 0.9 \pm 0.20, \mathrm{EC}_{25}: 0.5 \pm 0.05\right.$, NOEC: $<0.3$, LOEC $0.3 \mu \mathrm{g}^{-1}$ ) was also more phytotoxic than diuron $\left(\mathrm{EC}_{50}: 2.7 \pm 0.07, \mathrm{EC}_{25}: 1.2 \pm 0.07\right.$, NOEC: <0.3, LOEC $0.3 \mu \mathrm{g} \mathrm{l}^{-1}$, Fig. 2A,B). Replicate (repeat) toxicity tests conducted with $A$. formosa indicated similar $\mathrm{EC}_{50}$ values $\left(\mathrm{EC}_{50}: 1.7 \pm 0.13 \mu \mathrm{g} \mathrm{l}^{-1}\right.$ Irgarol 1051, $\mathrm{EC}_{50}: 2.9 \pm 0.05 \mu \mathrm{g} \mathrm{l^{-1 }}$ (Fig. 2A,B insets).

Acropora formosa that had been exposed to Irgarol 1051 or diuron for $24 \mathrm{~h}$ (see above) were placed in flowing seawater and $\Delta F / F_{\mathrm{m}}{ }^{\prime}$ monitored for several days to examine the recovery kinetics. After $8 \mathrm{~h}$ in flowing seawater (designated $t=0.5 \mathrm{~d}$ in Fig. 2), $\Delta F / F_{\mathrm{m}}{ }^{\prime}$ in Irgarol 1051-exposed corals was essentially the same as when measured during the toxicity test (i.e. after a $10 \mathrm{~h}$ exposure, Fig. 2A). Over the following days $\Delta F / F_{\mathrm{m}}$ ' gradually recovered, but after $4 \mathrm{~d}$ in flowing seawater, there were still significant differences between control corals and corals exposed to concentrations $>0.3 \mu \mathrm{g} \mathrm{l}^{-1}$ Irgarol 1051 (Fig. 2A, ANOVA p <

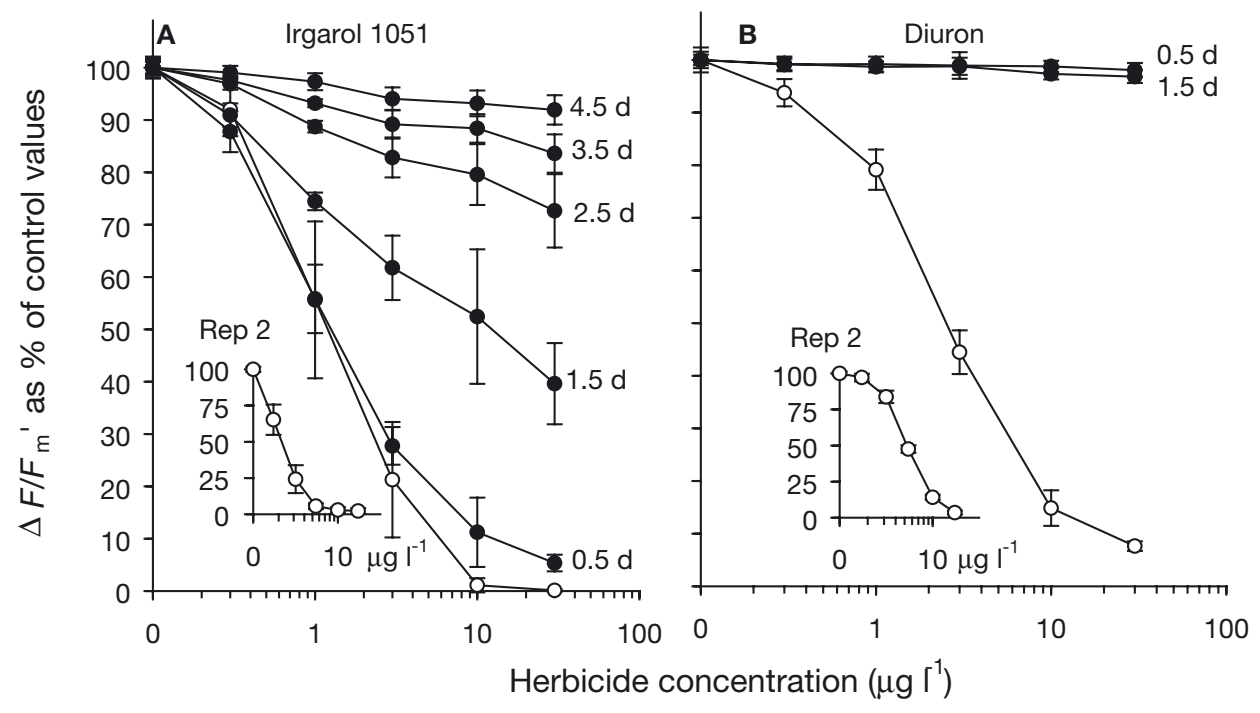

Fig. 2. Acropora formosa. $\Delta F / F_{\mathrm{m}}{ }^{\prime}$ of symbiotic dinoflagellates (in hospite) in A. formosa exposed to (A) elevated Irgarol 1051 or (B) diuron. Data for open symbols were calculated at the end of the $10 \mathrm{~h}$ light period and are normalized to control values. Corals were left in the herbicide solutions for a further $14 \mathrm{~h}$ (overnight) before transfer to flowing seawater. $\Delta F / F_{\mathrm{m}}{ }^{\prime}$ was measured again at 16:00 h (after $8 \mathrm{~h}$ in flowing seawater, designated $t=0.5 \mathrm{~d}$ ) and again at 16:00 h on successive days. Inset: replicate toxicity tests. Data are mean $(\bar{x}) \pm \operatorname{SD}(\mathrm{n}=9)$ 


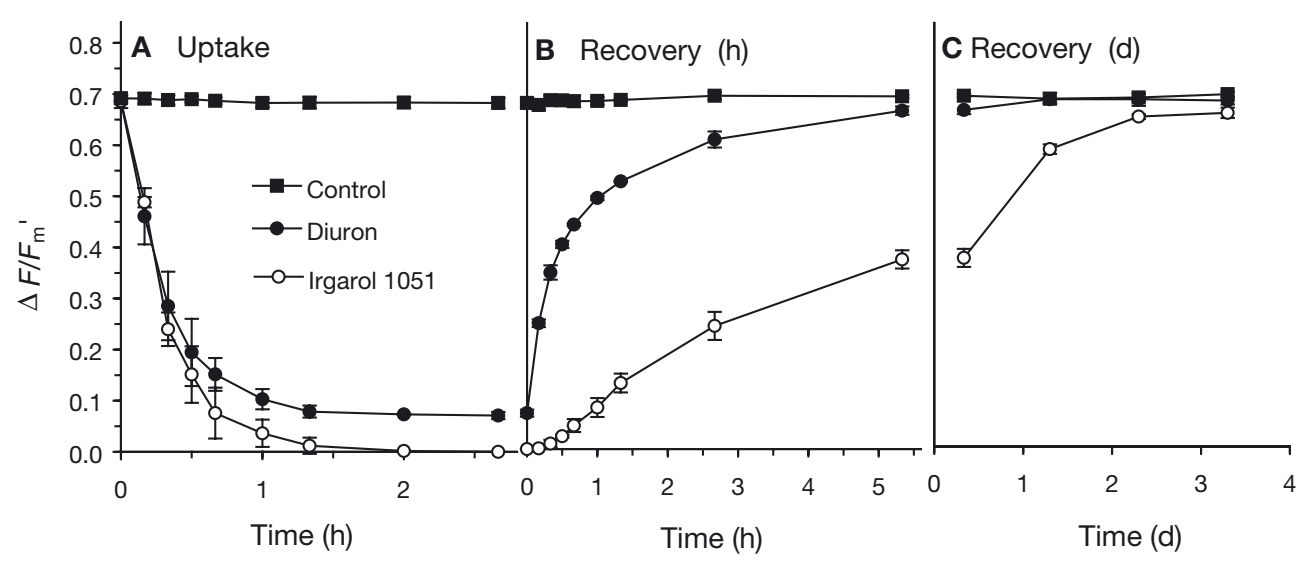

Fig. 3. Seriatopora hystrix. (A) $\Delta F / F_{\mathrm{m}}$ ' of symbiotic dinoflagellates (in hospite) in S. hystrix exposed to $3 \mu \mathrm{g} \mathrm{l}^{-1}$ diuron, Irgarol 1051 or ambient seawater (+carrier) for $160 \mathrm{~min}$. (B) Corals were then transferred to a $30 \mathrm{l}$ container receiving a supply of running seawater $\left(3 \mathrm{l} \mathrm{min}^{-1}\right)$ and $\Delta F / F_{\mathrm{m}}{ }^{\prime}$ measured at regular intervals for a further $5 \mathrm{~h}$. All experiments were conducted under $30 \mu \mathrm{mol}$ quanta $\mathrm{m}^{-2} \mathrm{~s}^{-1}$ artificial light. (C) Corals were then transferred to running seaway 'raceway' under $25 \%$ natural sunlight and $\Delta F / F_{\mathrm{m}}$ ' measured daily at $16: 00 \mathrm{~h}$ for a further $3 \mathrm{~d}$. Data are mean $(\bar{x}) \pm \mathrm{SD}(\mathrm{n}=3$ separate experiments). For each experiment, 4 corals were exposed to diuron or ambient seawater (+ carrier)

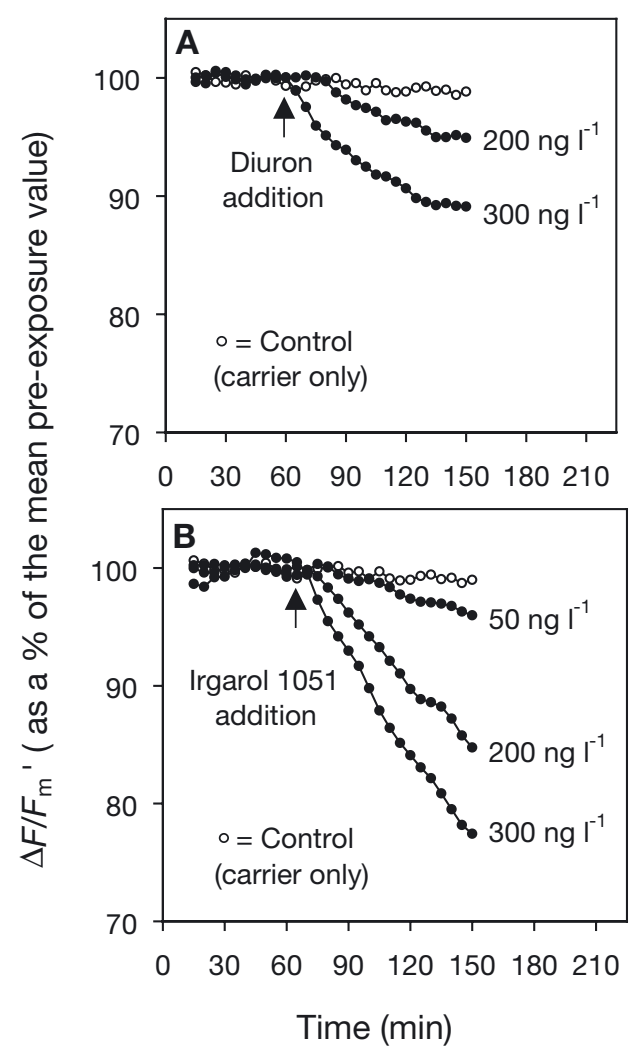

Fig. 4. Seriatopora hystrix. $\Delta F / F_{\mathrm{m}}{ }^{\prime}$ of symbiotic dinoflagellates (in hospite) in individual branches of $S$. hystrix measured a 5 min intervals for $1 \mathrm{~h}$ before exposure to (A) diuron $(100,200$, $300 \mathrm{ng} \mathrm{l}^{-1}$ ) or (B) Irgarol $1051\left(50,200,300 \mathrm{ng} \mathrm{l}^{-1}\right)$ for a further $1.5 \mathrm{~h}$. Control solutions were exposed to the carrier only after $1 \mathrm{~h}$
0.05). $\Delta F / F_{\mathrm{m}}{ }^{\prime}$ in $A$. formosa exposed to diuron for $24 \mathrm{~h}$ recovered more rapidly on its return to flowing seawater. Significant differences could be detected in $\Delta F / F_{\mathrm{m}}{ }^{\prime}$ between control corals and corals exposed to 10 and $30 \mathrm{Mg} \mathrm{l}^{-1}$ diuron at $t=0.5 \mathrm{~d}$ (Fig. 2B), but no differences could be detected after a further $24 \mathrm{~h}$ in flowing seawater (Fig. 2B, ANOVA p < 0.05).

In Seriatopora hystrix exposed to $3 \mu \mathrm{g} \mathrm{l^{-1 }}$ Irgarol 1051 or diuron, $\Delta F / F_{\mathrm{m}}$ ' decreased rapidly to $<50 \%$ of control values in $\sim 15 \mathrm{~min}$ (Fig. 3A). After $2 \mathrm{~h}$, there was no further decrease in $\Delta F / F_{\mathrm{m}}{ }^{\prime}$ which had fallen to $0 \%$ (Irgarol 1051) and $\sim 10 \%$ (diuron) of the control values. After a further $40 \mathrm{~min}$ in the herbicide solutions, corals were returned to flowing seawater to examine the recovery kinetics. In corals exposed to diuron, $\Delta F / F_{\mathrm{m}}{ }^{\prime}$ increased rapidly to $50 \%$ of control values in $20 \mathrm{~min}$ and to within $5 \%$ of control values in $5 \mathrm{~h}$ (Fig. 3B). In corals exposed to Irgarol 1051, $\Delta F / F_{\mathrm{m}}{ }^{\prime}$ recovered to within $50 \%$ of control values in $5 \mathrm{~h}$ and to within $5 \%$ of control values after a further $48 \mathrm{~h}$ in flowing seawater (Fig. 3C). After $72 \mathrm{~h}$ in flowing seawater, $\Delta F / F_{\mathrm{m}}{ }^{\prime}$ was still significantly different from control corals exposed to the carrier only (Fig. $3 \mathrm{C}$ ).

$\Delta F / F_{\mathrm{m}}{ }^{\prime}$ measured at 5 min intervals in fragments of Seriatopora hystrix incubated under $30 \mu \mathrm{mol}$ quanta $\mathrm{m}^{-2} \mathrm{~s}^{-1}$ PAR (at $25 \pm 1^{\circ} \mathrm{C}$ ) remained constant over a $1 \mathrm{~h}$ period (range 0.59 to 0.6 ). Following transfer to 200 and $300 \mathrm{ng} \mathrm{l}^{-1}$ diuron, and after a $1.5 \mathrm{~h}$ incubation, $\Delta F / F_{\mathrm{m}}{ }^{\prime}$ decreased by 5 and $10 \%$ of the pre-exposure values respectively (Fig. 4A). In fragments exposed to 50,200 and $300 \mathrm{ng} \mathrm{l}^{-1}$, Irgarol 1051, $\Delta F / F_{\mathrm{m}}{ }^{\prime}$ decreased by 5,20 and $30 \%$ respectively after $1.5 \mathrm{~h}$ exposure (Fig. 4B). 


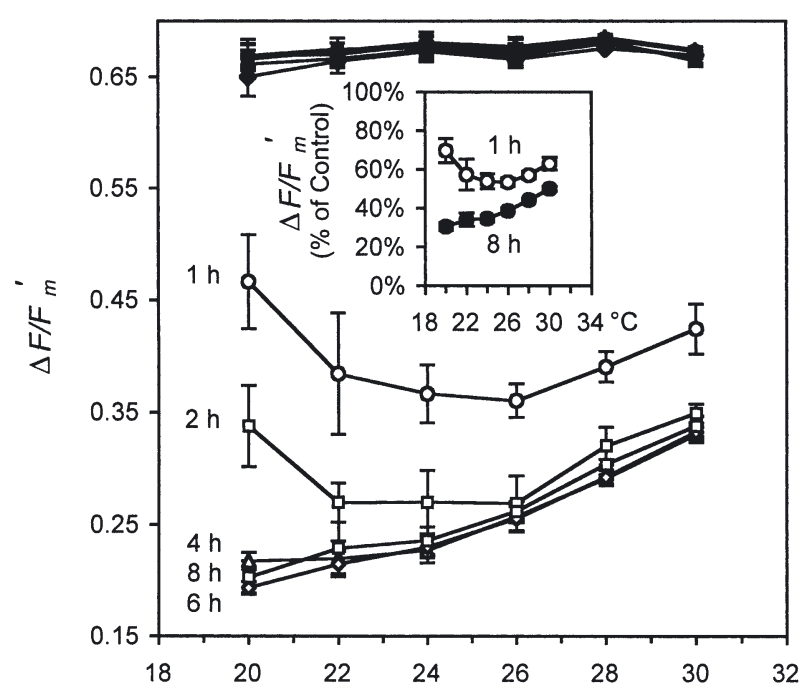

Fig. 5 Seriatopora hystrix. $\Delta F / F_{\mathrm{m}}{ }^{\prime}$ of symbiotic dinoflagellates (in hospite) in $S$. hystrix exposed to $3 \mu \mathrm{g} \mathrm{l}^{-1}$ diuron for $8 \mathrm{~h}$ at temperatures ranging from 20 to $30^{\circ} \mathrm{C}$ (open symbols) or control corals exposed to the carrier only (filled symbols). Experiments were conducted under $30 \mu \mathrm{mol}$ quanta $\mathrm{m}^{-2} \mathrm{~s}^{-1}$ photosynthetically active radiation (PAR) (artificial light). Inset: $\Delta F / F_{\mathrm{m}}{ }^{\prime}$ at 1 and $8 \mathrm{~h}$. expressed relative to control corals exposed to the carrier only. At each temperature, 3 containers were used for each control or herbicide solution, with 4 corals in each container. Data are mean $(\bar{x}) \pm \mathrm{SD}(\mathrm{n}=12$ corals $)$

After $1 \mathrm{~h}$ exposure to $3 \mu \mathrm{g} \mathrm{l^{-1 }}$ diuron, $\Delta F / F_{\mathrm{m}}{ }^{\prime}$ was lowest in Seriatopora hystrix fragments incubated at the middle of the temperature range (i.e. 24 and $26^{\circ} \mathrm{C}$ ) than at the ends of the temperature range (i.e. 20 and $30^{\circ} \mathrm{C}$ ), producing an inverted bell-shaped doseresponse relationship (Fig. 5). After $2 \mathrm{~h}, \Delta F / F_{\mathrm{m}}{ }^{\prime}$ was reduced further across all temperatures and after 4, 6 and $8 \mathrm{~h}$ was reduced further still, but mostly at the cooler $\left(20\right.$ and $\left.22^{\circ} \mathrm{C}\right)$ temperatures. The experiment was ended after $8 \mathrm{~h}$, by which stage $\Delta F / F_{\mathrm{m}}{ }^{\prime}$ was reduced to $30 \%$ of control values at $20^{\circ} \mathrm{C}$ and $50 \%$ of control values at $30^{\circ} \mathrm{C}$, giving an inverse relationship between temperature and diuron phytotoxicity. In control corals (exposed to the carrier only) there was little difference in $\Delta F / F_{\mathrm{m}}{ }^{\prime}$ between temperatures or at each sampling interval (Fig. 5).

Seriatopora hystrix were exposed to $30 \mathrm{\mu g} \mathrm{l}^{-1}$ Irgarol 1051 for $2 \mathrm{~h}$ each day for 4 successive days and in between the $2 \mathrm{~h}$ exposure periods the corals were returned to flowing seawater. Repetitive measurements of $\Delta F / F_{\mathrm{m}}{ }^{\prime}$ at 10 min intervals in 1 of the corals over the course of the first day show a rapid decrease in $\Delta F / F_{\mathrm{m}}{ }^{\prime}$ in association with the herbicide exposure (Fig. 6). On their return to running seawater, $\Delta F / F_{\mathrm{m}}{ }^{\prime}$ of the corals increased slightly but was significantly reduced compared with measurements of $\Delta F / F_{\mathrm{m}}{ }^{\prime}$ in control corals (which remained at $\sim 0.6$ to 0.7 over the course of the day, Fig. $6 \mathrm{~A}$ ). $\Delta F / F_{\mathrm{m}}{ }^{\prime}$ was also measured in all corals in the late afternoon $(16: 00 \mathrm{~h})$ each day, approximately $6 \mathrm{~h}$ after removal from the herbicide solutions. On Days 1 and $4 \Delta F / F_{\mathrm{m}}{ }^{\prime}$ was $\sim 35 \%$ of control values, and on Days 2 and $3 \Delta F / F_{\mathrm{m}}{ }^{\prime}$ was $\sim 50 \%$ of control values (Fig. 6B). Corals exposed to the intermittent herbicide treatment lost approximately $30 \%$ of their symbiotic dinoflagellates over the $4 \mathrm{~d}$ experiment, and
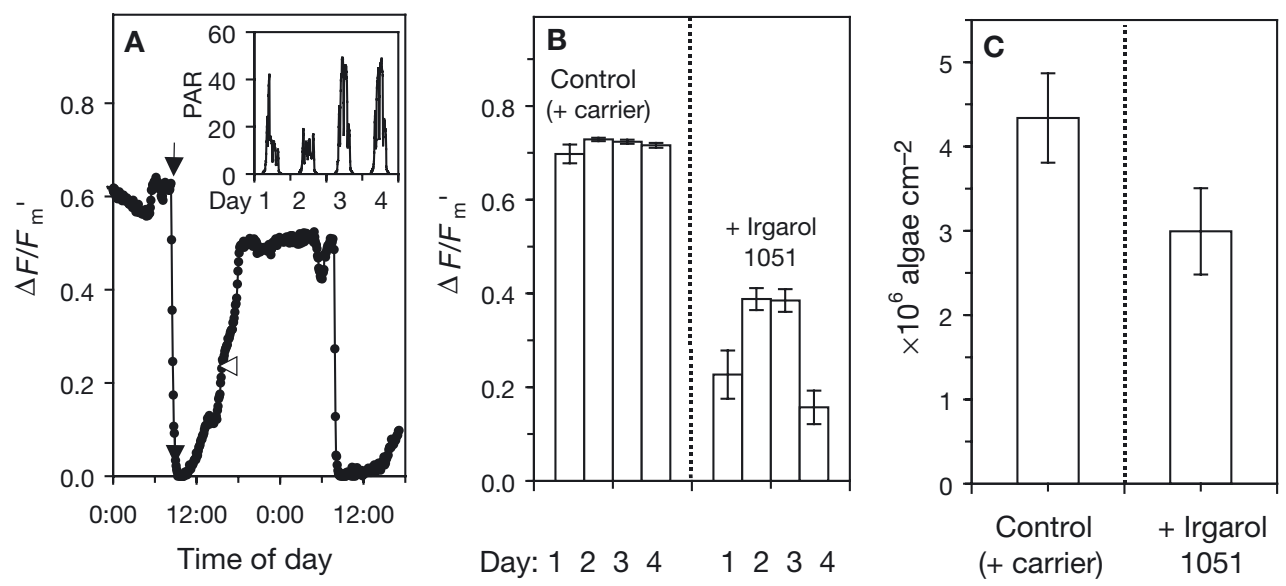

Fig. 6. Seriatopora hystrix. (A) $\Delta F / F_{\mathrm{m}}$ ' of symbiotic dinoflagellates (in hospite) in 1 colony of $S$. hystrix at 10 min intervals over the course of Day 1 of the $4 \mathrm{~d}$ experiment (see below and text). Corals were placed in $30 \mu \mathrm{g} \mathrm{l} \mathrm{l}^{-1} \operatorname{Irgarol} 1051$ at $08.00 \mathrm{~h}$ for $2 \mathrm{~h}$ each day for 4 consecutive days (arrow indicates placement of corals into and arrowhead removal from solutions). (A) Inset: PAR ( $\mu m o l$ quanta $\mathrm{m}^{-2} \mathrm{~s}^{-1}$ ) during the $4 \mathrm{~d}$ experiment. (B) $\Delta F / F_{\mathrm{m}}$ ' of symbiotic dinoflagellates (in hospite) in $S$. hystrix exposed to $30 \mu \mathrm{g} \mathrm{l}^{-1}$ Irgarol 1051 for $2 \mathrm{~h}$ each day for consecutive $4 \mathrm{~d}$ (see above). All measurements of $\Delta F / F_{\mathrm{m}}{ }^{\prime}$ were made in the late afternoon $(\sim 16: 00 \mathrm{~h})$; see open arrowhead in (A). (C) Symbiotic dinoflagellate density $\left(\times 10^{6}\right.$ algae $\left.\mathrm{cm}^{-2}\right)$ in colonies of $S$. hystrix at the end of the $4 \mathrm{~d}$ experiment. Data in $(\mathrm{B})$ and $(\mathrm{C})$ are mean $(\bar{x}) \pm \mathrm{SD}(\mathrm{n}=12)$ 
symbiotic algae densities in herbicide-exposed corals $\left(3 \pm 0.5 \times 10^{6}\right.$ algae $\mathrm{cm}^{-2}, \mathrm{n}=12$ corals $)$ was significantly different from control corals exposed to the carrier only for $2 \mathrm{~h}$ each day $\left(4.3 \pm 0.5 \times 10^{6}\right.$ algae per $\mathrm{cm}^{2}$, $\mathrm{n}=12$ corals, ANOVA $\mathrm{p}>0.05$, Fig. $6 \mathrm{C}$ ).

\section{DISCUSSION}

The effects of 8 PSII-herbicides from 4 different families (urea, triazine, triazinone, nitrile) on the symbiotic dinoflagellates of Seriatopora hystrix were assessed under controlled laboratory conditions of irradiance, temperature and water motion. Using a reduction in the maximal effective quantum yield of chlorophyll fluorescence $\left(\Delta F / F_{\mathrm{m}}\right)$ the phytotoxicity of the herbicides was ranked: Irgarol $1051>$ ametryn $\geq$ diuron $>$ hexazinone $>$ atrazine $>$ simazine $>$ tebuthiuron $>$ ioxynil. Overall, Irgarol 1051 was 3 times more phytotoxic than diuron and ametryn, 65 times more phytotoxic than atrazine and 250 times more phytotoxic than tebuthiuron. Studies with marine periphyton communities indicate similar results, with Irgarol 1051 more toxic than diuron (4 to 8 times) and 70 times more toxic than atrazine (Dahl \& Blanck 1996). Irgarol 1051, ametryn and atrazine are $s$-triazine herbicides, whilst diuron and tebuthiuron are phenyl urea types. Thus, of the 8 PSII-based herbicides tested, the toxicity varied by over 2 orders of magnitude, but there was no obvious relationship between toxicity and herbicide family.

Two studies have recently examined the effects of herbicides on corals at ultra low levels. Jones et al. (2003) examined the effects of diuron and atrazine on Acropora formosa, Montipora digitata and Porites cylindrica and reported absolute and relative $\mathrm{EC}_{50}$ values (diuron: 4 to $6 \mu \mathrm{g} \mathrm{l}^{-1}$, atrazine: 40 to $90 \mathrm{\mu g} \mathrm{l}^{-1}$ ) that are similar to those reported here. Owen et al. (2002) used ${ }^{14} \mathrm{C}$ uptake studies to examine the effects of the herbicide Irgarol 1051 on photosynthesis of symbiotic dinoflagellates freshly isolated from the coral Madracis mirabilis. Tests revealed significant effects on the isolated symbionts at concentrations of $63 \mathrm{ng} \mathrm{l}^{-1}$ after an exposure period of $>6 \mathrm{~h}$ (Owen et al. 2002). Studies were also conducted on the effects of algae in the intact symbiosis (in hospite) using photo-respirometry. Significant effects were noted after a $1.5 \mathrm{~h}$ exposure to $100 \mathrm{ng} \mathrm{l}^{-1}$ Irgarol 1051, although oxygen evolution results in herbicide-exposed corals were the same as control corals after longer periods. Owen et al. (2002) described highly variable rates of net photosynthesis (varying by over an order of magnitude); nevertheless, the results of Owen et al. (2002), Jones et al. (2003) and those reported here, suggest that Irgarol 1051 and diuron are powerful photosynthetic inhibitors of the symbiotic dinoflagellates of coral. When the algae are in the host tissues (in hospite), the photochemical efficiency of the algal symbionts can be significantly affected by concentrations at levels as low as $50 \mathrm{ng} \mathrm{l}^{-1}$ Irgarol 1051 and $200 \mathrm{ng} \mathrm{l}^{-1}$ diuron.

PSII-based herbicides typically reversibly bind to the $\mathrm{Q}_{\mathrm{B}}$ binding niche and can effectively be 'washed' from the binding site by returning the test material to clean running seawater. Vandermeulen et al. (1972) first reported the reversibility of inhibition in Pocillopora damicornis exposed to very high $\left(\mathrm{mg} \mathrm{l}^{-1}\right)$ diuron concentrations. Recently, Jones et al. (2003) reported the rapid recovery of photochemical efficiency in algae of Acropora formosa, Montipora digitata and Porites cylindrica exposed to $30 \mathrm{\mu g} \mathrm{l}^{-1}$ diuron or $100 \mathrm{\mu g} \mathrm{l}^{-1}$ atrazine when transferred to flowing seawater. Similarly, in the experiments reported here, the photochemical efficiency of algae in Seriatopora hystrix exposed to $30 \mathrm{~g} \mathrm{l}^{-1}$ diuron for $24 \mathrm{~h}$ recovered to normal levels within a few hours of its return to flowing seawater. In contrast, the photochemical efficiency of algae in both $S$. hystrix and A. formosa exposed to Irgarol 1051 recovered much more slowly under the same conditions, remaining inhibited for several hours/days. The urea/triazine families of PSII herbicides both bind to a common site in the $\mathrm{Q}_{\mathrm{B}}$ binding niche and as such are distinguishable from the phenol-type herbicides (Trebst 1987). Why the herbicidal properties of Irgarol 1051 relative to diuron and atrazine are so persistent is unclear, but it is a property that should be considered in environmental risk assessments associated with its use in antifouling paints.

In agricultural applications, offsite transport of diuron is usually associated with the first heavy rainfall event after application (in early spring). Rainfall that is sufficient to cause substantial discharge into the GBR usually occurs in the warmer summer months associated with tropical cyclones and the monsoon (Mitchell et al. 1996, Furnas \& Mitchell 1997). Thus, warmer temperature and reduced seawater salinity are 2 key variables that may affect diuron toxicity in the nearshore marine environment. Recently, Jones et al. (2003) reported that, in the short term, lower salinity does not have additive or synergistic effects on the phytotoxicity of diuron to the corals Acropora formosa and Montipora digitata. In this study, experiments were conducted between 20 and $30^{\circ} \mathrm{C}$, which is the yearly temperature range at the study site for average daily seawater temperatures (Jones et al. 2000). Results suggest that temperature has a complex effect on diuron phytotoxicity, involving at least 2 or more potentially antagonistic effects. For example, within the first few hours diuron is less phytotoxic to the symbiotic dinoflagellates of Seriatopora hystrix at 20 than $30^{\circ} \mathrm{C}$, but after 4 to $8 \mathrm{~h}$ exposure, becomes more phytotoxic at the lower temperature. 
Phytotoxicity depends upon inhibition at the site of action and target site delivery. Temperature affects the physicochemical properties of membranes (including permeability, fluidity, and lipid and protein complex mobility; Schreiber \& Berry 1977) as well as diffusional rates within tissues. Both are likely to affect the rate of penetration of the herbicide to the target sites. In isolated symbiotic dinoflagellates the response to diuron is rapid (i.e. within seconds to minutes), but in hospite the response is slower (i.e. minutes to hours; Jones et al. 2003). The difference between the studies in hospite and in vivo probably reflects the need for the herbicide to cross multiple animal tissue layers as well as the host cell membrane, the symbiosome membrane and possibly several membrane layers underlying the symbiosome (which are thought to be of algal origin; Wakefield \& Kempf 2001). At lower temperatures, diuron penetration to the target sites is initially slower; however, this effect progressively becomes less significant compared with an overall decreased sensitivity to diuron at warmer temperatures. Why diuron is less phytotoxic at 30 than $20^{\circ} \mathrm{C}$ may be related to conformational changes to the D1 protein binding-site that decrease the binding affinity and/or increased rates of D1 protein turnover and repair (Mattoo et al. 1989). Irrespective of the mechanisms associated with the effects of herbicide sensitivity, the results reported here suggest that seasonally elevated water temperatures should not markedly increase the toxicity of diuron to corals in the short term. The ecotoxicological parameters that have been presented here are from laboratory experiments conducted at $25 \pm 1^{\circ} \mathrm{C}$ and therefore represent an averaged response with respect to the 20 to $30^{\circ} \mathrm{C}$ annual temperature range experienced by the corals at the study site.

Longer-term studies of the effects of PSII inhibition by herbicides were conducted using short-term (2 h) pulses of Irgarol 1051. These pulses resulted in a suppression of the photochemical efficiency of the algal symbionts for most of the day (see Fig. 6A). Repeated exposure to Irgarol 1051 in this manner resulted in a dissociation of the symbiosis and a net loss of $30 \%$ of the algal symbionts in only $4 \mathrm{~d}$. A similar sublethal response has been reported in Montipora digitata exposed to elevated diuron concentrations (Jones et al. 2003). PSII inhibitors are only weakly toxic to nonphotosynthetic organisms. For example, in the bacteria Vibrio fisheri the LOEC for a reduction in luminescent light output (BioTox test system) after a 30 min incubation is $7.6 \mathrm{mg} \mathrm{l}^{-1}$ for diuron and $23 \mathrm{mg} \mathrm{l}^{-1}$ for Irgarol 1051 (Fernandez-Alba et al. 2002). For the crustacean Daphnia magna the LOEC for immobilization (Daphnotoxkit; following the OECD guideline 202 and ISO 6341 protocol) after a $24 \mathrm{~h}$ incubation is $2.4 \mathrm{mg} \mathrm{l}^{-1}$ for diuron and $3.5 \mathrm{mg} \mathrm{l}^{-1}$ for Irgarol 1051 (Fernandez-Alba et al. 2002). Unpublished studies with juvenile Acropora millepora also indicate that metamorphosis is not affected at diuron concentrations of 0.3 to $1 \mathrm{mg} \mathrm{l}^{-1}$ (Andrew Negri, Australian Institute of Marine Science [AIMS], pers. comm.). Since diuron and Irgarol 1051 are herbicidal at concentrations several orders of magnitude lower than levels that could affect the animal host, the dissociation of the symbiosis observed was due to suppression of the photochemical efficiency of the algae. Clearly, diuron and Irgarol 1051 are very useful photosynthetic inhibitors for examining the molecular, cellular, and physiological mechanisms associated with the phenomenon of bleaching of corals.

Consistent with their use in antifouling on the hulls of marine craft, the highest concentrations of Irgarol 1051 are found in marinas and harbours, with concentrations in temperate waters ranging from $<1$ to $1700 \mathrm{\mu g} \mathrm{l}^{-1}$ (Readman et al. 1993, Hall et al. 1999, Scarlett et al. 1999b, Thomas et al. 2001). Less information is known for tropical and subtropical waters, but Connelly et al. (2001) reported Irgarol 1051 concentrations ranging from 20 to $270 \mathrm{ng} \mathrm{l}^{-1}$ in harbours and semienclosed waters of Bermuda, and 10 to $20 \mathrm{ng} \mathrm{l}^{-1}$ Irgarol 1051 in more open locations. In a subsequent study of harbours in Bermuda, Owen et al. (2002) reported concentrations ranging from 40 to $300 \mathrm{ng} \mathrm{l}^{-1}$ Irgarol 1051, and concentrations of 3 to $20 \mathrm{ng} \mathrm{l}^{-1}$ in the more exposed opening to the northern lagoon. In marinas of the Florida Keys, Irgarol 1051 concentrations range between 10 and $100 \mathrm{ng} \mathrm{l}^{-1}$; $90 \mathrm{ng} \mathrm{l}^{-1}$ Irgarol 1051 has been measured in a harbour in St Croix (US Virgin Islands; Owen et al. 2002). Elevated diuron concentrations in temperate and subtemperate seas, enclosed seas and harbours have also been reported. Thomas et al. (2001) indicated that diuron concentrations in areas of high shipping/boating activity are generally 10 to $180 \mathrm{ng} \mathrm{l}^{-1}$, but levels as high as $6500 \mathrm{ng} \mathrm{l}^{-1}$ have been measured in one instance. In enclosed waters of the Spanish Mediterranean coast, Martinez et al. (2001) reported up to $2200 \mathrm{ng} \mathrm{l^{-1 }}$ diuron. No studies have measured diuron concentrations in tropical and subtropical coastal waters.

The levels of diuron in seawater inside the GBRMP are currently not known. Monitoring programmes are underway to examine levels of a number of key herbicides in the marine environment associated with agricultural practices and antifouling paint use. These include analysis of seasonal patterns and concentrations in episodic flood events. Nevertheless, levels in subtidal sediments of 1 to $10 \mu \mathrm{g} \mathrm{kg}^{-1}$ diuron have been measured, and partitioning models indicate that overlying water could reach concentrations of 100 to $1000 \mathrm{ng} \mathrm{l}^{-1}$ diuron (Haynes et al. 2000). Given the exceptionally low levels at which Irgarol 1051 and diuron can inhibit photosynthesis of the algal symbionts in corals, conta- 
mination of tropical coastal waters is a clear cause for concern. Assessments of herbicide concentration should to be incorporated into monitoring programmes where applicable. Policies and procedures for antifouling paint usage in tropical reefal waters should be reconsidered, especially where corals, isolated coral outcrops and coral reefs occur. The effects of herbicides leaching from antifouling paints should be more fully considered when evaluating the significance of proposed or existing marinas, harbours and designated mooring sites close to reefal areas.

Acknowledgements. This work received funding assistance from a Strategic Partnership with Industry - Research and Training (SPIRT) award from the Australian Research Council (ARC), the Great Barrier Reef Marine Park Authority (GBRMPA), The Townsville City Council, and the Natural Heritage Trust (Australia) under the Anti-fouling Program Project (\#29298).

\section{LITERATURE CITED}

Banin E, Israely T, Fine M, Loya Y, Rosenberg E (2001) Role of endosymbiotic zooxanthellae and coral mucus in the adhesion of the coral-bleaching pathogen Vibrio shiloi to its host. FEMS Microbiol Lett 199:33-37

Barnes DJ (1985) The effect of photosynthetic and respiratory inhibitors upon calcification in the staghorn coral, Acropora formosa. In: Gabrie C, Toffart JL, Salvat B (eds) Proceedings of the 5th International Coral Reef Symposium. Antenne Museum-EPHE, Tahiti, p 161-166

Connelly DP, Readman JW, Knap AH, Davies J (2001) Contamination of the coastal waters of Bermuda by organotins and the triazine herbicide Irgarol 1051. Mar Pollut Bull 32: $342-350$

Crossland CJ, Barnes DJ (1977) Gas-exchange studies with the Staghorn coral Acropora acuminata and its zooxanthellae. Mar Biol 40:185-194

Dahl B, Blanck H (1996) Toxic effects of the antifouling agent Irgarol 1051 on periphyton communities in coastal microcosms. Mar Pollut Bull 32:342-350

Duke NC, Roelfsema C, Tracey D, Godson L (2001) Preliminary investigation into dieback of mangroves in the Mackay Region: initial investigation into possible causes. Report to the Queensland Fisheries Service, Northern Region and the Community of Mackay Region. Mangrove Ecosystem Research \& Marine Botany Group, Botany Department, The University of Queensland, Brisbane (also available at www.dpi.qpi.gov.au/fishweb/5756.html)

Evans LV (1981) Marine algae fouling: a review with particular reference to ship-fouling. Bot Mar 14:167-171

Fernandez-Alba AR, Hernando MD, Piedra L, Chisti Y (2002) Toxicity evaluation of single and mixed antifouling biocides measured with acute toxicity bioassays. Anal Chim Acta 456:303-312

Furnas MJ, Mitchell AW (1997) Biological oceanography of the Great Barrier Reef. In: Anonymous (eds) Proceedings: The Great Barrier Reef, Vol 1. Science, Use and Management. Townsville, 25-29 November 1996. Great Barrier Reef Marine Park Authority, Townsville, p 75-87

Glynn PW, Howard LS, Corcoran E, Freay AD (1984) The occurrence and toxicity of herbicides in reef building corals. Mar Pollut Bull 15:370-374
Hall L Jr, Giddings JM, Solomon KR, Balcomb R (1999) An ecological risk assessment for the use of Irgarol 1051 as an algaecide for antifouling paints. Crit Rev Toxicol 29: $367-437$

Hamilton D, Haydon G (1996). Pesticides and fertilizers in the New South Wales sugar industry-estimates of usage and likely environmental fate. Department of Primary Industries, Resource Management Institute, Brisbane

Haynes D, Michalek-Wagner K (2000) Water quality in the Great Barrier Reef world heritage area: past perspectives, current issues and new research directions. Mar Pollut Bull 41:428-434

Haynes D, Müller J, Carter S (2000) Pesticide and herbicide residues in sediments and seagrasses from the Great Barrier Reef world heritage area and Queensland coast. Mar Pollut Bull 41:279-287

Hunter H, Sologinkin S, Choy S, Hooper A, Allen W, Raymond M, Peeters J (2001) Water management in the Johnstone Basin. Queensland Department of Natural Resources and Mines, Brisbane

Hutchings P, Haynes D (2000) Sources, fates and consequences of pollutants in the Great Barrier Reef. Mar Pollut Bull 41:265-266

Jones RJ, Ward S, Yang-Amri, Hoegh-Guldberg O (2000) Changes in quantum efficiency of Photosystem II of symbiotic dinoflagellates of corals after heat stress and during the 1998 Great Barrier Reef mass bleaching event. Mar Freshw Res 51:63-71

Jones RJ, Müller J, Haynes D, Schreiber U (2003) Effects of herbicides diuron and atrazine on corals of the Great Barrier Reef, Australia. Mar Ecol Prog Ser 251:153-167

Larcombe P, Woolfe K, Amjad N, Barnes D and 22 others (1996) Terrigenous sediment fluxes and the central Great Barrier Reef shelf: the current state of knowledge. In: Larcombe P, Woolfe K, Purdon R (eds) Great Barrier Reef: terrigenous sediment flux and human impacts. CRC Reef Research Centre, James Cook University, Townsville, p 7-23

Marshall AT, Wright A (1998) Coral calcification: autoradiography of a scleractinian coral Galaxea fascicularis after incubation in ${ }^{45} \mathrm{Ca}$ and ${ }^{14} \mathrm{C}$. Coral Reefs 17:37-47

Martinez K, Ferrer I, Hernando MD, Fernandez-Alba AR, Marce RM, Borrull F, Barcelo D (2001) Occurrence of antifouling biocides in the Spanish Mediterranean marine environment. Environ Technol 22(5): 543-552

Mattoo AK, Marder JB, Edelman M (1989) Dynamics of the photosystem II reaction center. Cell 56:241-246

Mitchell AW, Reghenzani JR, Hunter HM, Bramley RGV (1996) Water quality and nutrient fluxes from river systems draining to the Great Barrier Reef Marine Park. In: Hunter HM, Eyles AG, Rayment GE (eds) Downstream effects of land use. Department of Natural Resources, Brisbane, p 23-33

Müller JF, Duquesne S, Ng J, Shaw GR, Krrishnamohan K, Manonmanii K, Hodge M, Eaglesham GK (2000) Pesticides in sediments from irrigation channels and drains in Queensland. Mar Pollut Bull 41:294-301

Oettmeier W (1992) Herbicides of photosystem II. In: Barber J (ed) The photosystems: structure, function and molecular biology, Vol II. Elsevier, Amsterdam, p 349-408

Owen R, Knap A, Toaspern M, Carbery K (2002) Inhibition of coral photosynthesis by the antifouling herbicide Irgarol 1051. Mar Pollut Bull 44:623-632

Rand GM, Petrocelli SR (1985) Fundamentals of aquatic toxicology. Hemisphere Publishing, Washington, DC

Readman JW, Kwong LLW, Grondin D, Bartocci J, Villeneuve JP, Mee LD (1993) Coastal water contamination for a triazine herbicide used in antifouling paints. Environ Sci Technol 27:1940-1942 
Richardson LL, Smith GW, Ritchie KB, Carlton RG (2001) Integrating microbiological, microsensor, molecular and physiologic techniques in the study of coral disease pathogenesis. Hydrobiologia 460:71-89

Scarlett A, Donkin P, Fileman TW, Morris RJ (1999a) Occurrence of the antifouling herbicide, Irgarol 1051, within coastal-water seagrasses from Queensland, Australia. Mar Pollut Bull 38:687-691

Scarlett A, Donkin P, Fileman TW, Evans SV, Donkin ME (1999b) Risk posed by the antifouling agent Irgarol 1051 to the seagrass, Zostera marina. Aquat Toxicol (Amst) 45: $159-170$

Schreiber U, Berry J (1977) Heat-induced changes of chlorophyll fluorescence in intact leaves correlated with damage of the photosynthetic apparatus. Planta 136: $233-238$

Shick JM, Romaine-Lioud S, Ferrier-Pagès C, Gattuso JP (1999) Ultraviolet-B radiation stimulates shikimate pathway-dependent accumulation of mycosporine-like amino acids in the coral Stylophora pistillata despite decreases in its population of symbiotic dinoflagellates. Limnol Oceanogr 44:1667-1682

Simpson BW (2002) Water quality in the Pioneer Catchment on February 14-15, 2002. Water quality assessment and protection. Natural Resource Sciences, Natural Resources and Mines

Stimson J, Kinzie RA (1991) The temporal pattern and rate of

Editorial responsibility: Otto Kinne (Editor),

Oldendorf/Luhe, Germany release of zooxanthellae from the reef coral Pocillopora damicornis (Linnaeus) under nitrogen-enrichment and control conditions. J Exp Mar Biol Ecol 153:63-74

Thomas KV, Fileman TW, Readman JW, Waldock MJ (2001) Antifouling paint booster biocides in the UK coastal environment and potential risks of biological effects. Mar Pollut Bull 42:677-688

Trebst A (1987) The three-dimensional structure of the herbicide binding niche on the reaction center polypeptides of Photosystem II. Z Naturforsch 42:742-750

Vandermeulen JH, Davis ND, Muscatine L (1972) The effect of inhibitors of photosynthesis on zooxanthellae in corals and other marine invertebrates. Mar Biol 16:185-191

Veron JEN (1986) Corals of Australia and the Indo-Pacific. University of Hawaii Press, Honolulu

Voulvoulis N, Schrimshaw MD, Lester JN (1999) Alternative antifouling biocides. Appl Organomet Chemi 13:135-143

Wakefield T, Kempf S (2001) Development of host- and symbiont-specific monoclonal antibodies and confirmation of the origin of the symbiosome membrane in a Cnidariandiniflagellate symbiosis. Biol Bull 200:127-143

White I, Brodie J, Mitchell C (2002) Pioneer River catchment event based water quality sampling. Mackay Whitsundays Healthy Waterways Program, Mackay Whitsunday Regional Strategy Group, Mackay

Williams DMcB (2001) Impacts of terrestrial run-off on the GBRWHA. Report to CRC Reef, Townsville

Submitted: March 26, 2003; Accepted: June 13, 2003

Proofs received from author(s): September 15, 2003 